University of Montana

ScholarWorks at University of Montana

$12-1998$

\title{
Breeding Productivity Does Not Decline with Increasing Fragmentation in a Western Landscape
}

\author{
J. J. Tewksbury \\ Thomas E. Martin \\ University of Montana - Missoula, tom.martin@umontana.edu
}

Follow this and additional works at: https://scholarworks.umt.edu/wildbio_pubs

Part of the Life Sciences Commons

Let us know how access to this document benefits you.

\section{Recommended Citation}

Tewksbury, J. J. and Martin, Thomas E., "Breeding Productivity Does Not Decline with Increasing Fragmentation in a Western Landscape" (1998). Wildlife Biology Faculty Publications. 17.

https://scholarworks.umt.edu/wildbio_pubs/17

This Article is brought to you for free and open access by the Wildlife Biology at ScholarWorks at University of Montana. It has been accepted for inclusion in Wildlife Biology Faculty Publications by an authorized administrator of ScholarWorks at University of Montana. For more information, please contact scholarworks@mso.umt.edu. 


\title{
BREEDING PRODUCTIVITY DOES NOT DECLINE WITH INCREASING FRAGMENTATION IN A WESTERN LANDSCAPE
}

\author{
Joshua J. Tewksbury, ${ }^{1}$ Sallie J. Hejl, ${ }^{2}$ and Thomas E. Martin ${ }^{3}$ \\ 'Montana Cooperative Wildlife Research Unit, University of Montana, Missoula, Montana 59812 USA \\ ${ }^{2}$ USDA Forest Service, Rocky Mountain Research Station, P.O. Box 8089, Missoula, Montana 59807 USA \\ ${ }^{3}$ U.S. Biological Resources Division, Montana Cooperative Wildlife Research Unit, Avian Studies Program, \\ University of Montana, Missoula, Montana, USA
}

\begin{abstract}
Fragmentation of breeding habitat may cause declines in many bird populations. Our perception of the demographic effects of habitat fragmentation comes primarily from studies in the midwestern and eastern United States and Scandinavia. We know very little about the demographic effects of anthropogenically caused habitat fragmentation in habitats prone to natural disturbance, as is typical of most forest types in the western United States. We located and monitored 1916 nests on eight sites located in mostly forested landscapes and eight sites located in primarily agricultural landscapes to study the effects of landscape-level fragmentation on nest predation and brood parasitism in riparian areas in western Montana.

Patterns of nest predation were opposite those documented from more eastern locales; predation rates were higher in forested landscapes than in fragmented landscapes dominated by agriculture. This pattern probably reflects the importance of forest predators in these landscapes: red squirrels (Tamiasciurus hudsonicus) were much more abundant in forested landscapes and declined quickly with decreasing forest cover, whereas predators that typically increase in fragmented landscapes in the Midwest (such as corvids) increased only at very high levels of fragmentation. Patch size and distance to habitat edge did not influence predation rates. Brood parasitism by Brown-headed Cowbirds (Molothrus ater) decreased with increasing forest cover, but the strongest predictors of parasitism were the abundance of human development (farms and houses) on the landscape and the density of cowbird host species, not forest cover. The combined effects of predation and parasitism resulted in low nesting productivity in both forested and agricultural landscapes for heavily parasitized species, while the species not affected by cowbird parasitism had greater nesting productivity in fragmented agricultural landscapes. Our results suggest that the effects of fragmentation are dependent on the habitat structure, the landscape context, the predator community, and the impact of parasitism. All of these factors may differ substantially in western ecosystems when compared to previously studied forests, making generalizations about the effect of fragmentation difficult.
\end{abstract}

Key words: American Robin; brood parasitism; Brown-headed Cowbird; Cedar Waxwing; fragmentation, landscape; nest predation; riparian birds; Warbling Vireo; Yellow Warbler.

\section{INTRODUCTION}

Much of our understanding of the demographic effects of fragmentation comes from studies of bird populations (Ambuel and Temple 1983, Brittingham and Temple 1983, Howe 1984, Wilcove 1985, Temple 1986, Askins et al. 1990, Freemark and Collins 1992, Robinson 1992, Villard et al. 1992, Faaborg et al. 1995, Robinson et al. 1995, Brawn and Robinson 1996). Most of these studies focus on edge and patch size effects, but the composition of landscapes surrounding remaining fragments also can be important; studies in midwestern North America have shown that lower forest cover on the landscape is correlated with both higher nest predation and higher brood

Manuscript received 14 July 1997; revised 30 December 1997; accepted 31 December 1997. parasitism (Donovan et al. 1995, Robinson et al. 1995).

Landscapes in the eastern half of the United States historically were blanketed by contiguous hardwood forest, but many of these landscapes are now highly fragmented, and remaining forest patches are often surrounded by agriculture (Donovan et al. 1995, 1997, Robinson et al. 1995). In contrast, forest habitats in the western United States are often naturally patchy from extensive topographic variation and periodic disturbance from fire and flooding (Hejl 1992, 1994, Attiwill 1994, Ohmart 1994). Riparian habitats typify the patchy character of many western habitats and, in fact, tend to be patchy throughout the world. The demographic effects of humaninduced fragmentation in these naturally fragmented habitats may differ substantially from the effects seen in midwestern and eastern North America.

Increases in both nest predation and brood parasitism 




FIG. 1. (A) The study sites, spread over a 56-km section of the Bitterroot Valley, in Ravalli County, western Montana The white area is agricultural; black is forested. White circles with gray borders are sites in forested landscapes; gray circles with black borders are sites in agricultural landscapes. The figure also shows landscape features within $1 \mathrm{~km}$ of two sites, one forested (B), and one fragmented by agriculture and human development (C).

have been repeatedly correlated with habitat fragmentation (Gates and Gysel 1978, Brittingham and Temple 1983, Wilcove 1985, Gates and Griffen 1991, Paton 1994, Robinson et al. 1995, Donovan et al. 1997). However, many studies have relied on indirect data such as artificial nests (Wilcove 1985, Ratti and Reese 1988, Donovan et al. 1997; see Paton 1994 and Andrén 1995 for reviews of results from artificial nest studies), which may not reflect actual predation rates (Martin 1987, Willebrand and Marcström 1988, Roper 1992, Haskell 1995). Additionally, most studies have considered only local habitat characteristics, such as nest concealment, edge effects, and patch size effects, without considering landscape context (Andrén 1995). The abundance of predators and cowbirds in an area may depend more on characteristics of the surrounding landscape than on patch-specific habitat features, and thus the composition of larger landscapes may be critical in shaping predation and parasitism patterns at local scales (Andrén 1995, Donovan et al. 1997, Tewksbury et al., in press).

We explored patch size, edge, and landscape effects on nest predation and brood parasitism in deciduous riparian systems in western Montana and examined the demographic consequences for bird populations. Deciduous riparian habitats make up $<1 \%$ of the western
United States (Szaro 1980), yet they are the primary breeding grounds of $>60 \%$ of the passerine bird species in the western United States (Johnson et al. 1977, Knopf 1985, Knopf et al. 1988, Dobkin and Wilcox 1986, Saab and Groves 1992, Bock et al. 1993, Ohmart 1994). Here we provide the first study to examine the demographic consequences of landscape fragmentation around these critical western riparian habitats. We provide an important test of the generality of eastern fragmentation models by examining fragmentation effects in riparian habitats in the western United States, where both historical and current landscape patterns differ substantially from the Midwest and East.

\section{METHODS}

\section{Study area and study sites}

Study sites were located in the southern Bitterroot Valley, $70 \mathrm{~km}$ south of Missoula, Montana. Ranches, agricultural fields, and small towns dominate the valley. Forest cover increases west of the Bitterroot Valley in the foothills of the Bitterroot Mountains. This area is mostly Bitterroot National Forest land, managed for multiple use, timber production, and wilderness. Where National Forest land meets private land, a rough forestfarmland interface is formed (Fig. 1A). 
Sixteen study sites were established, eight in highly fragmented, agricultural landscapes along the Bitterroot River, and eight in largely unfragmented forested landscapes along smaller streams in the foothills of the Bitterroot Mountains (Fig. 1). These two landscape types (forested and agricultural) will be considered landscape treatments for examination of nest predation. Forest fragmentation does not occur randomly, and any large-scale examination of the effects of fragmentation must use existing landscape patterns. While no study has completely controlled for local differences between study locations unrelated to landscape features, we selected study sites so as to minimize differences on sites while still encompassing the full range of variation in landscapes surrounding sites. Though vegetation differences among sites were unavoidable, these differences were not strongly correlated with landscape features and did not explain differences in predation and parasitism among sites.

Sites averaged 12 ha in size and ranged in elevation from 1050 to $1350 \mathrm{~m}$. All sites were dominated by deciduous trees and shrubs typical of either the black cottonwood (Populus trichocarpa)/red-osier dogwood (Cornus stolonifera) community type, the quaking aspen (Populus tremuloides)/red-osier dogwood (Cornus stolonifera) habitat type, or the mountain alder (Alnus incana) community type (Hansen et al. 1995). All study sites were located in the same broad valley (Fig. 1A); thus, differences in predator and cowbird densities among sites reflect functional and numeric responses to local landscape and habitat differences, rather than differences in the regional abundance of predators and cowbirds caused by landscape variation at larger scales. However, our study sites were far enough apart to insure general independence of major predators and cowbirds among sites. Elsewhere, cowbirds have been shown to move large distances between feeding and breeding areas (Thompson 1994). However, where cowbirds have feeding and laying resources in close proximity, as we find in the Bitterroot Valley, they often move much smaller distances between feeding and laying areas (Thompson 1994). We used radiotelemetry to track nine female cowbirds laying on our study sites and found that no cowbirds used more than one area for breeding and breeding ranges were $<500 \mathrm{~m}$ long (J. J. Tewksbury, unpublished data). Additionally, cowbird movements between breeding and feeding areas were generally $<1 \mathrm{~km}$, as found elsewhere (Thompson 1994), suggesting that cowbird numbers and parasitism on sites was a function of local landscape character, and that sites were generally independent. To maximize our ability to detect landscape effects on predation and parasitism, we focused our analysis on species found in both fragmented, agricultural landscapes and unfragmented, forested landscapes.

\section{Landscape metrics}

Habitat type and land use coverages were developed for the study area and entered into a Geographic In- formation System using PC ARC/INFO (ESRI 1989). We obtained habitat and land use data by examining 1:15840 aerial photographs and delineating habitat polygons on orthophotographs. To verify habitat and land use types, we field-checked all mapped polygons during the study. A total of 31 different habitat types were described (Appendix). The local landscapes around each of the 16 study sites were defined at two spatial extents: all land within $1 \mathrm{~km}$ from the perimeter of the site (1-km extent; Fig. 1), and all land within 2 $\mathrm{km}$ from the perimeter (2-km extent). Larger landscapes were not considered because the observed variation in predation and parasitism rates could not be accounted for by using larger landscape scales, since the proximity of study sites created overlap in landscape area and tended to homogenize rather than to differentiate landscapes. FRAGSTATS spatial analysis software (McGarigal and Marks 1995) was used to compute landscape metrics around each site at both landscape extents. Percent cover of the major habitat types consistently portrayed the overall character of the landscape regardless of changes in landscape extent, while other metrics generated by FRAGSTATS, such as habitat patch size and habitat patch density, were difficult to interpret and dependent on the landscape extent. Therefore, all landscape metrics analyzed are the percentage of the local landscapes covered by the habitat or land use type of interest.

\section{Patch size and edge effects}

The deciduous riparian habitats of our study are naturally fragmented by river channels and other vegetation types, and thus $55 \%$ of all nests monitored were within $100 \mathrm{~m}$ of some edge type, and very few nests were further than $200 \mathrm{~m}$ from some edge. To examine patch size and edge effects, we defined the patch size of our study sites as the area of deciduous vegetation bounded on all sides by any other habitat type (e.g., agriculture, coniferous forest) or a river channel $>25$ $\mathrm{m}$ wide. We measured the distance to the two closest edges within $100 \mathrm{~m}$ of each nest, and did not consider adjacent habitat further than $100 \mathrm{~m}$ from the nest. Edge types considered here include deciduous riparian habitat abutting agricultural fields, water, coniferous forest, and meadows.

\section{Variables influencing predation and parasitism}

The percentage of local landscapes covered by forest has been used most often to quantify habitat fragmentation in relation to nesting success and brood parasitism (Andrén 1992, Donovan et al. 1995, Robinson et al. 1995). We therefore examined the relationship between percentage forest cover and both nest predation and brood parasitism. However, we found cowbirds most often feeding in areas associated with human habitations, such as farms and houses, not simply landscapes with low forest cover. The Bitterroot Valley is predominantly rural, and most houses have either a 
TABLE 1. Species parasitized by the Brown-headed Cowbird.

\begin{tabular}{|c|c|c|c|c|}
\hline & & \multicolumn{2}{|c|}{$\begin{array}{c}\text { Percentage Parasitized } \\
(\text { no. nests } \dagger)\end{array}$} & \multirow{3}{*}{$\begin{array}{l}\text { Primary } \\
\text { hosts? }\end{array}$} \\
\hline \multicolumn{2}{|c|}{ Species } & \multirow[b]{2}{*}{ All nests } & \multirow{2}{*}{$\begin{array}{l}\text { Whole } \\
\text { period }\end{array}$} & \\
\hline Common name & Scientific name & & & \\
\hline \multicolumn{5}{|l|}{ More common host species } \\
\hline Common Yellowthroat & Geothlypis trichas & $71(7)$ & $\ldots(4)$ & $\mathrm{Y}$ \\
\hline Song Sparrow & Melospiza melodia & $66(32)$ & $64(11)$ & $\mathrm{Y}$ \\
\hline Warbling Vireo & Vireo gilvus & $63(68)$ & $73(26)$ & $\mathrm{Y}$ \\
\hline Yellow Warbler & Dendroica petechia & $61(131)$ & $63(57)$ & $\mathrm{Y}$ \\
\hline Solitary Vireo & Vireo solitarius & $58(12)$ & $\cdots(6)$ & $\mathrm{Y}$ \\
\hline Veery & Catharus fuscescens & $40(10)$ & $\cdots(3)$ & $\mathrm{Y}$ \\
\hline American Redstart & Setophaga ruticilla & $41(61)$ & 38 (29) & $\mathrm{Y}$ \\
\hline Willow Flycatcher & Empidonax trailii & $37(35)$ & $40(15)$ & $\mathrm{Y}$ \\
\hline Orange-crowned Warbler & Vermivora celata & $33(6)$ & $\cdots(2)$ & $\mathrm{Y}$ \\
\hline MacGillivray's Warbler & Oporornis tolmiei & $32(19)$ & $\ldots(5)$ & $\mathrm{Y}$ \\
\hline Dusky Flycatcher & Empidonax wrightii & $24(76)$ & $27(48)$ & $\mathrm{Y}$ \\
\hline Swainson's Thrush & Catharus ustuatus & $12(26)$ & $\ldots(6)$ & $\mathrm{N}$ \\
\hline Dark-eyed Junco & Junco hyemalis & $6(17)$ & $\ldots(2)$ & $\mathrm{N}$ \\
\hline Red-winged Blackbird & Agelaius phoeniceus & $5(37)$ & $\ldots(9)$ & $\mathrm{N}$ \\
\hline Chipping Sparrow & Spizela passerina & $0(9)$ & $\cdots(4)$ & $\mathrm{N}$ \\
\hline \multicolumn{5}{|l|}{ Less common host species } \\
\hline Red-eyed Vireo & Vireo olivaceus & $100(4)$ & $\cdots(2)$ & $\mathrm{Y}$ \\
\hline Lazuli Bunting & Passerina amoena & $100(3)$ & $\cdots(0)$ & $\mathrm{Y}$ \\
\hline Audubon's Warbler & Dendroica coronata & $100(2)$ & $\ldots(1)$ & $\mathrm{Y}$ \\
\hline Nashville Warbler & Vermivora ruficapilla & $100(1)$ & $\ldots(0)$ & $\mathrm{Y}$ \\
\hline Hammond's Flycatcher & Empidonax hammondii & $67(3)$ & $\cdots(1)$ & $\mathrm{Y}$ \\
\hline
\end{tabular}

$\dagger$ Numbers of nests monitored in which parasitism was known (from 1995 and 1996). To examine potential bias of including nests found later in the nesting cycle, we compared parasitism rates using all nests to parasitism rates using only nests found before clutch initiation (whole period). Bias associated with using all nests is minimal for all species (Pearson's $\chi^{2}>$ 0.2 in all cases). Whole-period parasitism rates are not calculated for species with $<10$ nests.

$\$$ Primary hosts are species with $>15 \%$ of their nests parasitized $(\mathrm{Y}=$ yes, $\mathrm{N}=$ no). Only primary hosts are used to control for host density.

small corral, or an area where chicken or wild bird food is abundant. Cowbirds use all these resources for feeding. Consequently, we designated human habitation as all development, including farm buildings, corrals, livestock holding areas, and residential development, and included this metric in our analysis of brood parasitism. We analyzed percentage cover of human habitation rather than actual density to be consistent with other landscape metrics. Thus the importance of an individual farm is a function of its size, and a landscape with larger farms has more human habitation than a landscape with an equal number of smaller farms (Fig. $1 \mathrm{~B}, \mathrm{C})$.

\section{Assessing predation rates, parasitism rates, and relative abundance}

During the 1995 and 1996 breeding seasons, a total of 1916 nests of 74 species were found and monitored to determine fledging success and parasitism using methods described in Martin and Geupel (1993).

Nest fate was determined by checking nest status every two to four days. Most nests were approached at least once to determine clutch size. We used mirror poles and ladders to access high nests. We modified fate protocols established by Martin et al. (1996), to account for cowbird parasitism and provide a standardized decision tree for nest fate determination that minimized bias. Predation was assumed when the nest was torn apart, destroyed, or found empty with no sign of inclement weather after the first egg was laid and before the expected fledge date. Predation rates were estimated using the Mayfield method (Mayfield 1961, 1975) as modified by Hensler and Nichols (1981). This method determines the number of nests lost per day of nest exposure to correct for potential biases associated with finding some nests later in the nesting cycle (any day after the first egg is laid). Predation was determined on a treatment level (eight sites embedded in forested landscapes vs. eight sites in agriculturally dominated landscapes; Fig. 1) for the American Robin (Turdus migratorius), Cedar Waxwing (Bombycilla cedrorum), Warbling Vireo (Vireo gilvus), Yellow Warbler (Dendroica petechia), and Back-headed Grosbeak (Pheucticus ludovicianus), the only five open-cup nesting species that were sufficiently abundant in both treatments. Cavity-nesting species are not considered in this paper.

Brood parasitism by the Brown-headed Cowbird was determined for 550 nests. The percentage of nests parasitized was measured on a site by site basis, both by pooling nests across all prime host species (Table 1) and by examining parasitism rates on Yellow Warblers and Warbling Vireos separately. These species were the only two sufficiently abundant to allow us to estimate parasitism rates across individual sites. Parasitism rates 
reported are the percentage of nests parasitized, rather than a daily parasitism rate (Woodworth, in press $a$ ). Though daily parasitism rates may correct for potential bias associated with differing periods of susceptibility to brood parasitism (Pease and Grzybowski 1995), the percentage of nests parasitized on our sites was highly correlated with daily parasitism (Pearson's correlation; $n=16, r=0.95, P<0.0005$ for all hosts; $n=9, r$ $=0.90, P=0.001$ for Yellow Warblers; and $n=8, r$ $=0.87, P=0.005$ for Warbling Vireos). Thus, the use of daily parasitism would not improve our analysis or change our results, and interpretation would be more difficult. Neither the percentage of nests parasitized nor daily parasitism accounts for the potential bias that may result when nests are found after clutch initiation, and many nests are abandoned early in the nesting cycle due to parasitism. When this occurs, reported rates of parasitism may be less than actual parasitism, as nests found later in the nesting cycle are more often unparasitized. To examine this possibility, we compared parasitism rates for all nests monitored with parasitism rates calculated using only nests found before clutch initiation.

We conducted point count surveys of all birds on all sites over the two seasons. Following methods outlined in Hutto et al. (1986), each point count location was censused three times per season, each count was 10 min long, and all birds seen or heard in a 50-m radius from the point were recorded. Relative abundance was determined from a total of 450 counts censused on 82 point locations between dawn and 1100. Point locations were systematically distributed on sites such that each point was $>200 \mathrm{~m}$ from all other points. The number of points per site varied from 2 to 8 as a function of site size. We examine the relationship between the relative abundance of the two most common predators on our sites-red squirrels (Tamiasciurus hudsonicus) and Black-billed Magpies (Pica pica) —and landscape features. Although other predators were also present in lesser numbers, these two species made up over $90 \%$ of all predator detections. We also present relative abundance of cowbirds and cowbird hosts. We considered all species in which $>15 \%$ of nests were parasitized in this analysis (Table 1, prime hosts). In our analysis of the effect of host density on brood parasitism rates, we calculated the estimated marginal mean of host density on each site from an ANOVA with year and site included as main effects. Host density was calculated as the mean number of detections per point location averaged across all locations on a site.

We tested for between-year variation in cowbird abundance, predation rates, and parasitism rates, as an interaction between annual variation and study site or landscape treatment could confound our results if years are pooled. If no interaction is observed, annual variation in these metrics makes detection of biological differences more difficult, but will not confound results.

\section{Nesting productivity}

Nest predation and brood parasitism accounted for $>90 \%$ of nest losses. As these processes may interact to reduce annual fecundity, we examined the joint impact of these processes on four species common to both landscape types-two that are rarely parasitized and reject cowbird eggs (American Robin and Cedar Waxwing), and two that are heavily impacted by brood parasitism (Warbling Vireo and Yellow Warbler). We did not include Black-headed Grosbeak in this analysis as our information on parasitism rates for this species is not complete. We constructed a simple model incorporating our data on predation pressure and parasitism rates in the two landscape treatments with the effect of parasitism on the number of young fledged from successful nests. By combining these data, we estimated the mean number of young fledged per nesting attempt in both forested landscapes $\left(F_{F}\right)$ and agricultural landscapes $\left(F_{\mathrm{A}}\right)$ :

$$
\begin{aligned}
& F_{\mathrm{F}}=\left(\mathrm{NS}_{\mathrm{F}} \mathrm{SP}_{\mathrm{F}} F_{\mathrm{wp}}\right)+\left(\mathrm{NS}_{\mathrm{F}}\left[1-\mathrm{SP}_{\mathrm{F}}\right] F_{\mathrm{np}}\right) \\
& F_{\mathrm{A}}=\left(\mathrm{NS}_{\mathrm{A}} \mathrm{SP}_{\mathrm{A}} F_{\mathrm{wp}}\right)+\left(\mathrm{NS}_{\mathrm{A}}\left[1-\mathrm{SP}_{\mathrm{A}}\right] F_{\mathrm{np}}\right)
\end{aligned}
$$

where NS is Mayfield adjusted nesting success in each landscape treatment, SP is the percentage of successful nests parasitized in each landscape treatment, $F_{\text {wp }}$ is the average number fledged for parasitized nests, and $F_{\text {np }}$ is the average number fledged for unparasitized nests. This approach incorporates Mayfield adjusted nesting success and partitions the effects of parasitism and predation; thus, it is less biased and more flexible than the standard approach of simply dividing the total number of young fledged for a species by the number of nests monitored. However, nesting productivity should not be confused with seasonal reproductive success, which must account for renesting effort. We do not address seasonal reproductive success here.

\section{Data analysis}

Our examination of predation included one paired $t$ test of landscape treatment, four ANOVA tests of edge type, and one regression of predation rate vs. patch size. To correct for inflation of significance due to multiple testing, we use sequential Bonferroni adjustment of significance (Rice 1989) for the six tests. To examine parasitism, we tested forest cover, host density, and the extent of human habitation. Prior to analysis, percentile metrics were arcsine square-root transformed where necessary (Zar 1984). All three of these tests were conducted with all primary host species pooled and for two individual species for which we had sufficient sample size (nine tests). We also examined the independent effects of forest cover and human habitation on parasitism rates on all primary hosts pooled. Correction for multiple tests is thus based on 11 tests.

To determine the landscape size that best predicted predator and parasite densities on our sites, we used the GLM procedure in SPSS version 7 (SPSS 1996) 
TABLE 2. Relationship between the abundance of censused predators and cowbirds on 16 study sites and landscape metrics measured at two spatial extents (1- and 2-km radius landscapes) around each site.

\begin{tabular}{|c|c|c|c|c|c|c|c|}
\hline \multirow{2}{*}{$\begin{array}{l}\text { Landscape } \\
\text { variable }\end{array}$} & \multirow{2}{*}{$\begin{array}{l}\text { Abundance } \\
\text { on sites } \dagger\end{array}$} & \multicolumn{3}{|c|}{ Entered first } & \multicolumn{3}{|c|}{ Entered second } \\
\hline & & Extent & $F$ & $P$ & Extent & $F$ & $P$ \\
\hline Forest cover & Squirrel & $\begin{array}{l}1 \mathbf{k m} \\
2 \mathrm{~km}\end{array}$ & $\begin{array}{l}14.2 \\
13.4\end{array}$ & $\begin{array}{c}<\mathbf{0 . 0 0 0 5} \\
0.003\end{array}$ & $\begin{array}{l}2 \mathrm{~km} \\
1 \mathrm{~km}\end{array}$ & $\begin{array}{l}0.1 \\
0.9\end{array}$ & $\begin{array}{l}0.712 \\
0.353\end{array}$ \\
\hline Forest cover & Magpie & $\begin{array}{l}1 \mathrm{~km} \\
2 \mathbf{~ k m}\end{array}$ & $\begin{array}{l}12.6 \\
14.6\end{array}$ & $\begin{array}{l}0.004 \\
\mathbf{0 . 0 0 2}\end{array}$ & $\begin{array}{l}2 \mathrm{~km} \\
1 \mathrm{~km}\end{array}$ & $\begin{array}{l}4.4 \\
2.3\end{array}$ & $\begin{array}{l}0.056 \\
0.153\end{array}$ \\
\hline $\begin{array}{l}\text { Residential } \\
\text { development } \neq\end{array}$ & Cowbird & $\begin{array}{ll}1 & \mathbf{~ k m} \\
2 \mathrm{~km}\end{array}$ & $\begin{array}{r}11.2 \\
9.9\end{array}$ & $\begin{array}{l}\mathbf{0 . 0 0 5} \\
0.008\end{array}$ & $\begin{array}{l}2 \mathrm{~km} \\
1 \mathrm{~km}\end{array}$ & $\begin{array}{l}1.3 \\
0.0\end{array}$ & $\begin{array}{l}0.283 \\
0.987\end{array}$ \\
\hline
\end{tabular}

Notes: For each test $(n=16)$ two models were run using Type I sums of squares. In the first model, the $1-\mathrm{km}$ extent was forced first, followed by the $2-\mathrm{km}$ extent; in the second model the $2-\mathrm{km}$ extent was forced first. This was done to determine which landscape extent explains a higher proportion of the variance in density among sites (has a higher $F$ value) when forced first in the model. Variables entered second act only on variation not explained by the first variable entered. The most relevant extent is highlighted in boldface type for each species considered.

$\uparrow$ From fixed radius point counts.

\$ Log transformed.

and the percentage cover of habitat types at both the 1- and 2-km landscape extents. Using Type I sums of squares, we forced a landscape variable at the $1-\mathrm{km}$ extent first and then added the same variable at the 2$\mathrm{km}$ extent. We then reversed the procedure, first forcing the variable at the $2-\mathrm{km}$ extent and adding the $1-\mathrm{km}$ extent second (Table 2). Landscape features were highly correlated between spatial extents (Pearson's correlation coefficient $>0.75$ in all cases), primarily because the larger landscape extent includes the smaller landscape. Therefore, the extent entered first always explained the vast majority of variation in predator and parasite numbers (Table 2). However, variation in Brown-headed Cowbird and red squirrel densities on our sites were slightly better explained by forcing the $1-\mathrm{km}$ landscape extent first, while magpie detections were slightly better explained by forcing the 2-km extent first (Table 2). Because 1-km extents provided a better fit for the most abundant predator censused and for cowbirds, we use 1-km landscapes for all following analyses. However, our results do not change when the $2-\mathrm{km}$ extent is used.

Differences in predation rates between years and between species and landscape types were examined using program CONTRAST (Hines and Sauer 1989), which uses a chi-square statistic to test for homogeneity of survival rates by creating a linear contrast of the rate estimates (Sauer and Williams 1989). Differences in predation rates between forested landscapes and fragmented agricultural landscapes were examined using a paired $t$ test on mean daily predation rates blocking by species and testing for a landscape affect. The five most abundant species were included in this analysis.

For analysis of the effects of edge on predation rates, we calculated exposure days as the number of days the nest was active from first egg laid until the date of predation or success. We restricted our analysis to nests found on or before the third day of incubation that had either failed due to predation or were successful. As these data were normally distributed, edge distance was used as a covariate in an ANCOVA design in which site and species were included as main effects to control for differences among landscapes and species. The hypothesis that smaller patches would have higher predation rates was examined using linear regression for the five most common species combined, as well as for American Robins separately, as they were the only species with sufficient nest numbers to be compared among plots.

Forest cover and agricultural land were strongly related (Pearson's correlation, $n=16, r=-0.826, P<$ $0.0005)$. These two variables essentially index the same landscape variation, and so only forest cover is tested, to allow comparisons with previous studies. We used partial regression analysis to examine the independent relationships between parasitism and forest cover, patch area, and human habitation; we tested each while controlling for the effects of the other two variables. Thus, the partial $F$ statistic and associated partial $R^{2}$ for each landscape variable measure the additional explanatory contribution of that variable after the effects of the other variables have been accounted for. We used the same technique to separate cumulative host density and human habitation to examine their independent effects on parasitism rates.

\section{RESUlts}

\section{Annual variation}

Nest predation did not differ between years for any of the individual species or for all species combined ( $\chi^{2}, P>0.15$ in all cases). Brood parasitism also did not differ between years for either of the two species analyzed separately or for all prime hosts combined $\left(\chi^{2}, P>0.2\right.$ in all cases). We therefore pooled data 


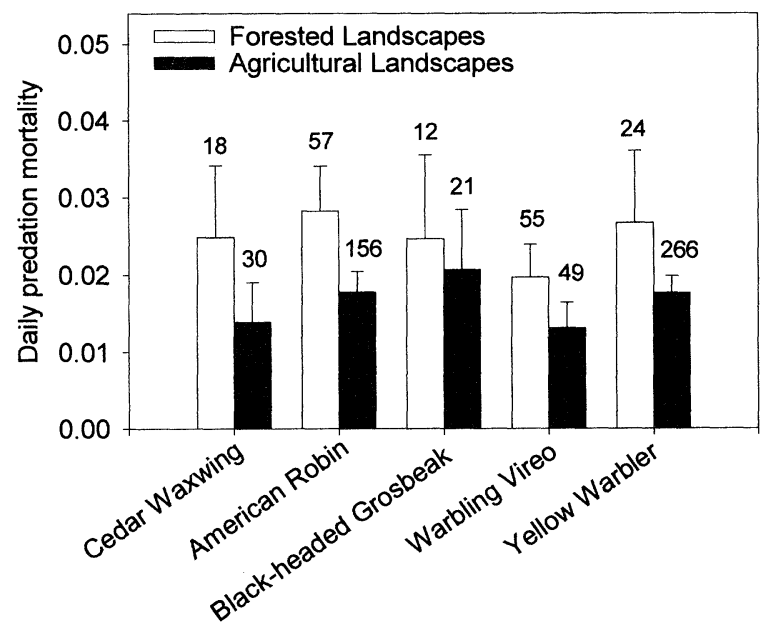

FIG. 2. Daily mortality due to predation for the five opencup nesting species for which we have sufficient sample size (shown above error bars) in both forested and agricultural landscapes. Error bars are maximum-likelihood estimators. A two-tailed, paired $t$ test on mean predation mortality for each species by treatment combination was significant after Bonferroni correction ( $t=6.3$, df $=4, P=0.003)$.

from both years. Neither predator (red squirrel or Black-billed Magpie) showed significant variation between years (Mann-Whitney $U$, red squirrel $P=0.41$, Black-billed Magpie $P=0.15$ ). Cowbird abundance was higher in 1996 (ANOVA, $F=10.6$, df $=1,35$, $P=0.003)$, but no interaction was found between year and site $(F=0.568$, df $=14,55, P=0.878)$. Cumulative host density was also higher in $1996(F=$ 6.13 , df $=1,20, P=0.022$ ) but we found no interaction between year and site $(F=1.291$, df $=14,54, P=$ 0.24 ). Therefore, site differences were independent of yearly variation in both cases, and years were pooled.

\section{Predation}

Nest predation was higher in forested, less fragmented landscapes than in agricultural landscapes $(t=$ $6.3, P=0.003$, Fig. 2). Every open-cup nesting species with sufficient sample size ( $\geq 30$ nests) showed the same trend. Predation rates may vary for a number of reasons, but much of the variance in our system may be explained by predator densities. Red squirrel density was much higher in forested landscapes $\left(r^{2}=0.53, P\right.$ $=0.001$; Fig. 3A), while magpies were only found on sites with extremely low forest cover (Fig. 3B). However, the overall relative abundance of red squirrels was 10 times greater than that of magpies, and squirrels outnumbered magpies on all but two sites (paired $t$ test, $t=3.98, \mathrm{df}=15, P=0.001)$.

Predation rates were not affected by the distance from any habitat edge types tested (Table 3 ). Patch size also showed no relationship with predation pressure either on American Robins $\left(r^{2}=0.06, \mathrm{df}=12, P=\right.$ $0.4)$ or all five species combined $\left(r^{2}=0.11\right.$, df $=13$, $P=0.254)$.

\section{Parasitism}

Brown-headed Cowbirds regularly parasitized 16 primary host species on our sites (Table 1). Parasitism rates did not change substantially for any species when the analysis was restricted to nests found before clutch initiation (Table 1, Pearson's $\chi^{2}$, all $P>0.2$ ), therefore, all further analyses are conducted on the larger sample of all nests.

Parasitism decreased with higher forest cover when all prime host species were considered together (Fig. 4A). However, though the same trend is apparent for individual species, the relationship was not significant after correction for multiple tests (Fig. 4B, C). Forest cover and human habitation were positively correlated, and when we included forest cover, patch size, and human habitation in a partial regression analysis, human habitation was the only landscape variable explaining variation in parasitism rates among sites (Table 4 ). We therefore used human habitation instead of forest cover in all further analyses of parasitism.

When we combined all host species and examined parasitism pressure in relation to both human habitation and cumulative host density, both independent relationships were highly significant (Fig. 5A, B). When we considered species individually, both relationships remained highly significant (Fig. 5C-F), and the predictive strength of both relationships generally increased (Fig. 5C, D, F).

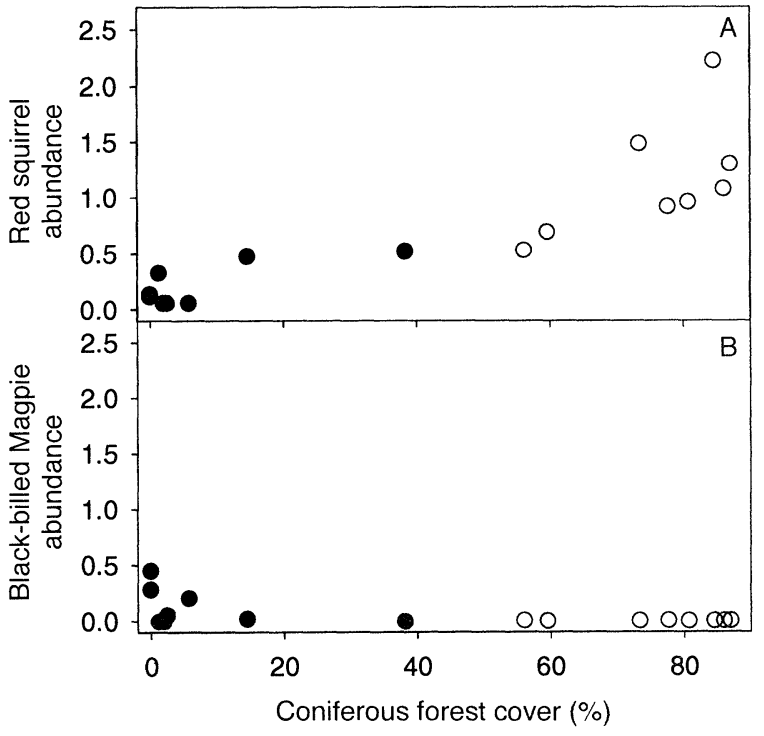

FIG. 3. Mean abundance of red squirrels and Black-billed Magpies on our study sites (number of detections per 50-m fixed radius point count), as a function of percentage of coniferous forest cover on 1-km landscapes. Red squirrels (A) increased with increasing forest cover, while Black-billed Magpies (B) only occurred on sites with very low coniferous forest cover. Open circles $(O)$ represent sites in forested landscapes; closed circles $(-$ represent sites in agricultural landscapes. 
TABLE 3. Results from ANCOVA tests for four different edge types. The dependent variable is survival days, site and species are entered as main effects, and distance to edge is a linear covariate.

\begin{tabular}{|c|c|c|c|c|c|c|c|c|c|c|c|c|}
\hline \multirow[b]{2}{*}{ Source of variation } & \multicolumn{3}{|c|}{ Field } & \multicolumn{3}{|c|}{ Meadow } & \multicolumn{3}{|c|}{ Water } & \multicolumn{3}{|c|}{ Conifer } \\
\hline & $\mathrm{df}$ & $F$ & $P$ & df & $F$ & $P$ & df & $F$ & $P$ & $\mathrm{df}$ & $F$ & $P$ \\
\hline Species & 10 & 1.264 & 0.30 & 17 & 1.463 & 0.12 & 21 & 1.214 & 0.24 & 17 & 0.946 & 0.52 \\
\hline Site & 9 & 0.896 & 0.54 & 14 & 1.974 & 0.03 & 10 & 1.481 & 0.15 & 12 & 1.373 & 0.19 \\
\hline Distance to edge & 1 & 0.807 & 0.38 & 1 & 1.226 & 0.27 & 1 & 0.309 & 0.58 & 1 & 0.417 & 0.52 \\
\hline Site $\times$ Distance to edge & & & & 14 & 1.298 & 0.22 & 9 & 1.215 & 0.29 & 12 & 0.778 & 0.67 \\
\hline Species $\times$ Distance to edge & & & & 17 & 1.371 & 0.16 & & & & & & \\
\hline Error & 28 & & & 13 & & & 23 & & & 13 & & \\
\hline
\end{tabular}

Notes: Degrees of freedom are variable as the number of species and nests that were in proximity to different edge types varied. After adjusting for multiple tests, we found no effects of distance to edge on predation rates.

\section{Nesting productivity}

Nesting success of Cedar Waxwings in agricultural areas was almost twice as high as in forested landscapes, where $<25 \%$ of nests were successful (Table 5). Similarly, American Robin nesting success was higher in fragmented landscapes dominated by agriculture. As a result, the number of young fledged per nesting attempt was lower in forested landscapes for both these species (Fig. 6). Neither of these species was affected by brood parasitism, and thus this difference was due almost entirely to higher nest predation in forested landscapes (Fig. 2). In contrast, Yellow War-

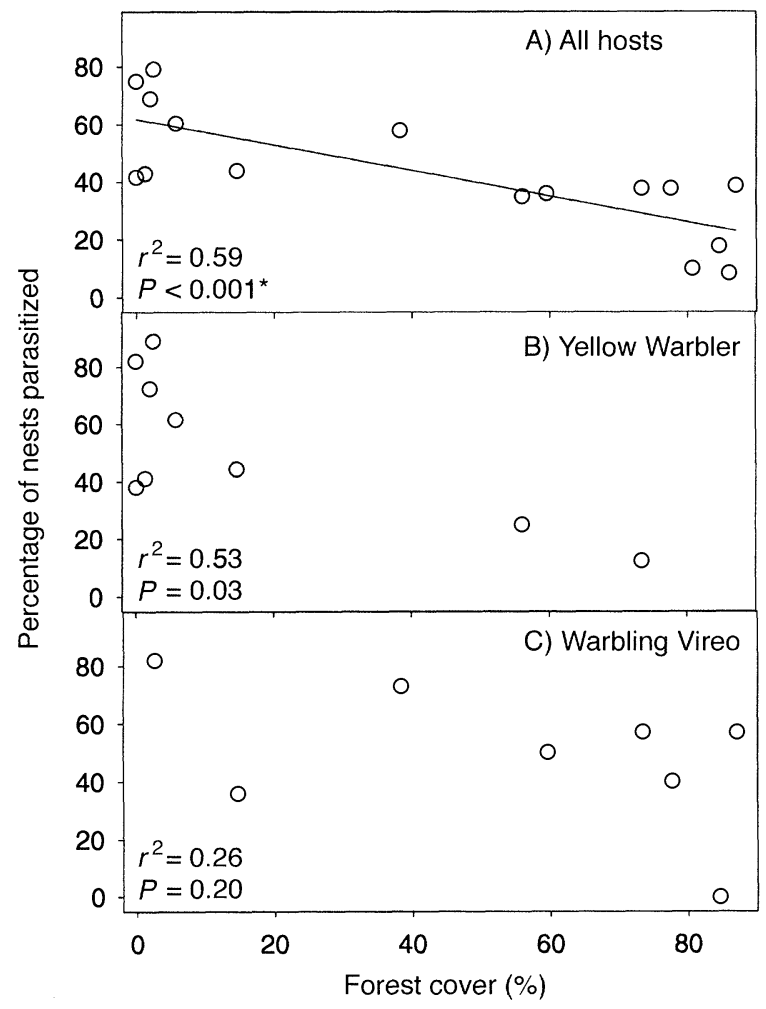

FIG. 4. Relationship between parasitism rates and percentage forest cover, showing all hosts pooled (A), followed by the two most abundant species considered individually, Yellow Warbler (B) and Warbling Vireo (C). The asterisk (*) indicates significance after Bonferroni correction. blers and Warbling Vireos are both heavily parasitized and showed equally low nesting productivity in both landscapes (Fig. 6). However, the causes of low productivity were different in the two landscapes. In fragmented landscapes, nest predation on Yellow Warblers and Warbling Vireos was lower than in forested landscapes, as seen with the nonparasitized species, but nest loss due to parasitism was much higher. We considered two ways in which parasitism decreases nesting productivity: nest failure due to abandonment or death of all natal young, and reduction in the number of young fledged from successful nests due to cowbird egg ejection and competition with cowbird nestlings. Both of these factors decreased nesting productivity further in fragmented landscapes (Table 5) where cowbirds are more abundant. Increased parasitism in fragmented landscapes may also reduce renesting potential, as birds that only fledge cowbirds are constrained by fledgling care, as are birds raising natal fledglings, and thus may not renest. This impact is not considered in the current paper.

\section{DISCUSSION}

\section{Predation}

Studies from the midwestern United States suggest that predation rates increase rapidly with decreasing forest cover and increasing agriculture on the landscape (Andrén 1992, Donovan et al. 1995, Robinson et al. 1995). We found the opposite. For the five most common species present across both landscapes, nest predation was greater in predominantly forested landscapes than in fragmented agricultural areas. Ultimately, predation rates should reflect the differences in predator communities associated with different landscape configurations (Andrén 1995). In midwestern and eastern North America and Scandinavia, increased fragmentation and agriculture are often associated with large increases in corvids, racoons, skunks, and squirrels (Andrén 1992, Faaborg et al. 1995). In contrast, in our system, the density of the most abundant nest predator, the red squirrel, declined in increasingly fragmented, agricultural landscapes, and although Blackbilled Magpies increased in these areas, they were never very abundant. Ravens and Stellers Jays were de- 
TABLE 4. Partial regression coefficients between percentage of nests parasitized and patch size, forest cover, and percentage human habitation within $1 \mathrm{~km}$ of each study site in the Bitterroot Valley in western Montana.

\begin{tabular}{lccl}
\hline \hline \multicolumn{1}{c}{ Variable } & $B_{\mathrm{st}}$ & $R_{\text {part }}^{2}$ & \multicolumn{1}{c}{$P$} \\
\hline Patch size & 0.031 & $<0.01$ & 0.83 \\
Forest cover & -0.07 & 0.01 & 0.78 \\
Human habitation & 0.83 & 0.50 & $0.005^{*}$ \\
\hline
\end{tabular}

Note: Data are percentage of all nests parasitized for all primary hosts (see Table 1) on each study site; $n=16$ study sites, 531 nests. The standardized partial regression coefficient $\left(B_{\mathrm{si}}\right)$, the partial $R^{2}\left(R_{\mathrm{pari}}^{2}\right)$, and the associated $P$ values measure the effect of one factor after accounting for the effects of the other factors.

* Significant relationship after Bonferroni adjustment.

tected very rarely on our sites, and incidental observations of fox, chipmunks, weasels, racoons, and skunks were recorded in both landscapes, but their relative abundance has not been quantified. However, red squirrels are known to be important nest predators in western North American forest systems (Martin $1993 a$ ), and the abundance of forest predators such as squirrels may have a stronger influence on nest predation in western systems than in areas studied in eastern North America.

The lack of patch size or edge effects found in the Bitterroot Valley runs counter to results from studies in eastern North America, where historically contiguous habitats have been fragmented by human land use (Gates and Gysel 1978, Chasko and Gates 1982, Brittingham and Temple 1983, Wilcove 1985, Small and Hunter 1988, Yahner 1988, Møller 1989). However, recent work in the Midwest suggests that edge effects are dependent on landscape context (Donovan et al. 1997). Western riparian habitats are linear and patchy by nature; very little of the habitat we studied was $>150 \mathrm{~m}$ from an edge of some kind. Additionally, though patch size varied considerably among sites, patches were not very isolated from other deciduous habitat, and most edges were with water and mead-
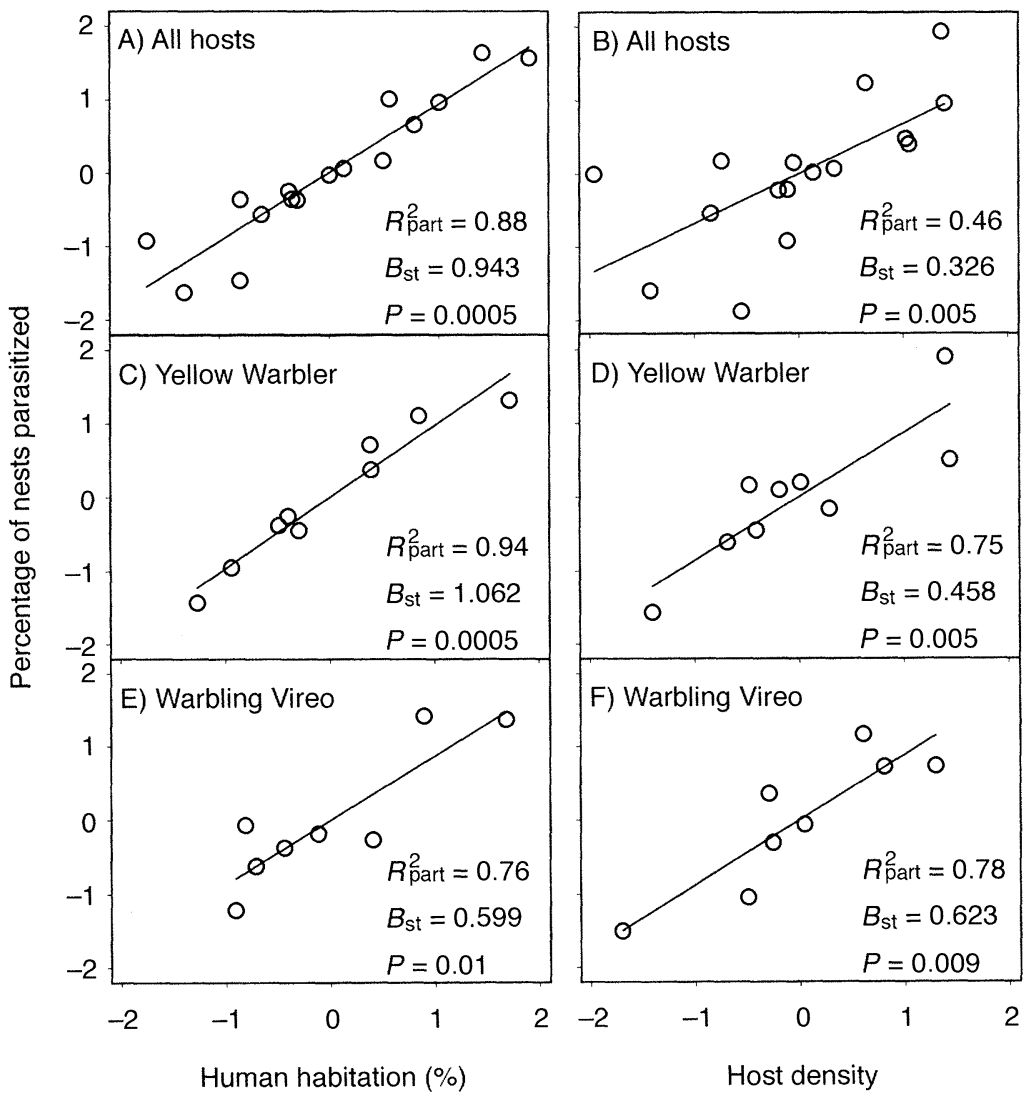

FIG. 5. Partial regression residual plots illustrating the relationship between parasitism rates and human habitation (A, C, E) and host density (B, D, F). The plots show parasitism pressure on all prime cowbird hosts combined (A), on Yellow Warbler (C), and on Warbling Vireo (E) as a function of percentage of human habitation, while controlling for the density of all potential hosts, and the relationship between the density of all prime hosts and parasitism pressure on all prime hosts (B), on Yellow Warbler (D), and on Warbling Vireo (F), while controlling for human habitation. Prime hosts are listed in Table 1. Sample sizes are 531 nests on 16 sites for all hosts, 153 nests on 9 sites for Yellow Warblers, and 87 nests on 8 sites for Warbling Vireos. $B_{\mathrm{st}}=$ standardized partial regression coefficient. All relationships were significant after controlling for multiple tests. 
TABLE 5. Nesting parameters for the four most common open-cup nesting species on sites in fragmented agricultural landscapes and unfragmented forested landscapes in the Bitterroot Valley of western Montana; these parameters are used in Eqs. 1 and 2 to generate nesting productivity. The mean number fledged from parasitized and unparasitized nests is calculated for both landscape types combined. Sample sizes are shown in parentheses.

\begin{tabular}{|c|c|c|c|c|c|c|}
\hline \multirow{2}{*}{$\begin{array}{l}\text { Species and } \\
\text { landscape } \dagger\end{array}$} & \multicolumn{2}{|c|}{ Daily nest mortality } & \multirow[b]{2}{*}{ NS } & \multirow[b]{2}{*}{ SP§ } & \multirow[b]{2}{*}{$\left(F_{\mathrm{np}}\right) \|$} & \multirow[b]{2}{*}{$\left(F_{\mathrm{wp}}\right) \mathrm{I}$} \\
\hline & Predation & Parasitism & & & & \\
\hline Cedar Waxwin & & & & & & \\
\hline $\begin{array}{l}\text { Forested } \\
\text { Agricultural }\end{array}$ & $\begin{array}{l}0.0248 \\
0.0138\end{array}$ & $\begin{array}{l}0.0 \\
0.0\end{array}$ & $\begin{array}{l}24.9 \pm 1.8(18) \\
46.4 \pm 2.2(30)\end{array}$ & 0.0 & $2.88(9)$ & NA \\
\hline American Robi & & & & & & \\
\hline $\begin{array}{l}\text { Forested } \\
\text { Agricultural }\end{array}$ & $\begin{array}{l}0.0282 \\
0.0178\end{array}$ & $\begin{array}{l}0.0 \\
0.0\end{array}$ & $\begin{array}{l}33.7 \pm 5.7(57) \\
50.2 \pm 4.7(156)\end{array}$ & 0.0 & $2.93(57)$ & NA \\
\hline $\begin{array}{l}\text { Warbling Vireo } \\
\text { Forested } \\
\text { Agricultural }\end{array}$ & $\begin{array}{l}0.0197 \\
0.0130\end{array}$ & $\begin{array}{l}0.0081 \\
0.0130\end{array}$ & $\begin{array}{l}32.6 \pm 5.1(55) \\
32.7 \pm 4.6(49)\end{array}$ & $\begin{array}{l}11.1(9) \\
27.3(11)\end{array}$ & $3.1 \quad(10)$ & $2.0(3)$ \\
\hline $\begin{array}{l}\text { Yellow Warble } \\
\text { Forested } \\
\text { Agricultural }\end{array}$ & $\begin{array}{l}0.0267 \\
0.0176\end{array}$ & $\begin{array}{l}0.0067 \\
0.0132\end{array}$ & $\begin{array}{l}29.1 \pm 9.2(24) \\
35.7 \pm 6.1(266)\end{array}$ & $\begin{array}{cc}0.0 & (4) \\
50 \quad(38)\end{array}$ & $3.5 \quad(13)$ & $2.2(10)$ \\
\hline
\end{tabular}

$\dagger$ Forested $=8$ study sites with $>50 \%$ forest cover in the $1-\mathrm{km}$ landscape surrounding the site; agricultural $=8$ study sites with $<50 \%$ forest cover.

$\$$ Mayfield adjusted percentage of nests successful (daily nest success raised to the power of the nesting interval), plus or minus maximum-likelihood standard deviation for overall nesting success (Johnson 1979).

$\S$ Percentage of successful nests that were parasitized.

$\|$ Mean number of young fledged from successful nonparasitized nests. Data are from all nests in which the exact number fledged is known.

If Average number of natal young fledged from successful nests that were parasitized. Success = at least 1 natal young fledged. Data are from all nests in which the exact number fledged is known; NA = not applicable.

ows-habitats that may not themselves attract predators. The natural patchiness and lack of isolation probably both contribute to the lack of any consistent edge effect.

Thus habitat fragmentation in the western United States does not necessarily lead to higher predation rates. Though this finding, and the lack of any evidence for increased predation around habitat edges, is different from results from other parts of North America, it is similar to fragmentation effects throughout much

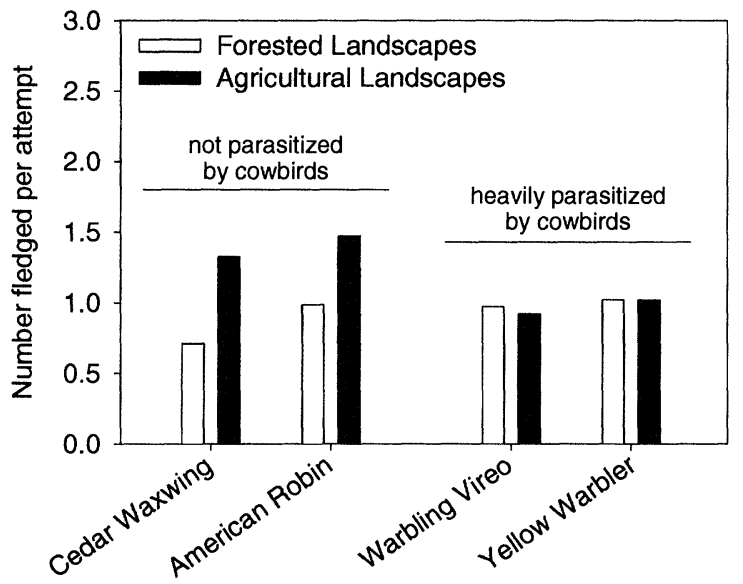

FIG. 6. Combined impact of nest predation and brood parasitism on the fecundity of two species not parasitized by cowbirds and two heavily parasitized species. The mean number of young fledged per attempt was determined using demographic data from Table 5 and Eqs. 1 and 2. of Europe, where predation rates are lower in human settled areas (Martin and Clobert 1996). Fragmentation of hardwood forests in the midwestern United Sates and other formerly contiguous habitats appears to cause an increase in generalist predators that often use habitat edges (Andrén 1992, Donovan et al. 1995, Robinson et al. 1995). This increase must outweigh decreases in forest interior predators, with the result that predation rates rise in fragmented habitats. In western deciduous forests the balance may be shifted, such that the decline of forest predators associated with landscape fragmentation is more pronounced than the increase in generalist predators.

\section{Parasitism}

Forest cover has been repeatedly used to predict cowbird abundance and brood parasitism in the midwestern United States (Robinson 1992, Robinson and Wilcove 1994, Donovan et al. 1995, 1997, Robinson et al. 1995). However, our data show that forest cover may not always be a good predictor of parasitism. In the present study, the variables most directly related to the rates of brood parasitism are those directly linked to the life history of the cowbird: food resources and the density of hosts. Forest cover is only weakly correlated with parasitism pressure on individual species, both in the current study (Fig. 4C-D) and in the Midwest (Robinson et al. 1995), where parasitism on four of eight species studied showed no significant relationships with forest cover. In contrast, human habitation was strongly correlated with parasitism rates in our study. 
Primary cowbird feeding areas include short-grass fields, livestock corrals, feedlots, and bird-feeders (Verner and Ritter 1983, Rothstein et al. 1984, 1987, Thompson 1994; M. L. Johnson and J. J. Tewksbury, unpublished data). All of these areas are associated with human habitation in the Bitterroot Valley, and probably elsewhere in the West. Therefore, the proximity of human habitation, representing feeding areas for cowbirds, may have a greater affect on parasitism than does the percentage of a landscape that is forested.

Independent of feeding resources, the cumulative density of hosts also affected parasitism rates. Other studies have shown that cowbirds are more abundant in habitat types with greater cumulative host density (Verner and Ritter 1983, Rothstein et al. 1984, Robinson and Wilcove 1994, Tewksbury et al., in press) but the effect of variance in cumulative host density within a habitat has received little study (Barber and Martin 1997). Our results suggest that cowbirds congregate where host density is high and subsequently parasitize a greater proportion of nests.

Human habitation and host density represent direct links to the foraging and reproductive biology of the cowbird. The strong independent relationships of both these variables with parasitism suggest that cowbirds are attempting to minimize travel distances while maximizing both reproductive opportunities and foraging efficiency. Application of these relationships may allow spatially explicit predictions of parasitism rates over broad landscape scales.

\section{Nesting productivity}

The largest demographic impacts faced by most birds on their breeding grounds are nest predation and brood parasitism (Brittingham and Temple 1983, Trail and Baptista 1989, Martin 1992, 1993b, 1996, Pease and Grzybowski 1995, Brawn and Robinson 1996, Woodworth, in press $b$ ). In some landscapes, fragmentation may cause increases in both predators and cowbirds, resulting in large differences in breeding productivity between forested landscapes and fragmented agricultural landscapes (Donovan et al. 1995, Robinson et al. 1995, Brawn and Robinson 1996). However, in the Bitterroot Valley, riparian areas in fragmented landscapes have lower predation rates, but high rates of cowbird parasitism. Thus, overall nesting productivity depends on the relative importance of these processes on different species. Nonparasitized species, such as the Cedar Waxwing and American Robin, fledge between 1.4 and 1.5 young per nesting attempt in agricultural landscapes (Fig. 5). Given current estimates of survival (Martin 1995), pairs would need an average of only two nesting attempts per season for local recruitment to balance mortality. Riparian habitats in agricultural settings in the Bitterroot Valley thus appear to serve as population sources for these species. In contrast, populations of the same species nesting in forested landscapes may need an average of 3.5 to 4.5 nesting attempts per season to achieve a stable population. American Robins may achieve such levels (J. J. Tewksbury, unpublished data), but Cedar Waxwings probably do not, and thus these forested areas are likely population sinks for Cedar Waxwings. The large difference in productivity, due to differences in predation rates between landscapes, may cause local source-sink dynamics to occur for some nonparasitized species. For heavily parasitized species, higher parasitism in agricultural areas decreases productivity to levels equal to or below productivity in forested areas. Because of high parasitism in fragmented landscapes and high predation in forested areas, Yellow Warblers and Warbling Vireos nesting in either landscape fledge only 0.9 to 1.0 young per attempt. At that fecundity level, Yellow Warblers, which do not raise multiple broods in our system, would need to attempt between three and seven renests following nest failure to achieve stable population levels. Warbling Vireos, which commonly raise multiple broods, would need to initiate between three and four nesting attempts to achieve stable population growth. Clearly, we need better estimates of both adult and juvenile survival to make more precise estimates of population health for these species, but our results indicate that neither landscape type studied in the Bitterroot Valley offers a strong source habitat for these species due to the dual affects of predation and parasitism.

\section{Conclusions}

Landscape-level processes determining predation and parasitism pressure may be more complex than often appreciated. Predation patterns in any landscape depend on the response of different predator species to landscape composition, and on the relative effects of these predators on different bird species. Because of the complex nature of these interactions, universal relationships between fragmentation and nest predation are unlikely. However, parasitism pressure may be predicted with a high degree of accuracy by considering those variables that relate directly to the resources used by cowbirds - food and hosts. Because cowbirds use similar types of resources throughout their range, relationships between landscape features and parasitism rates derived in one location may be applicable to many others.

This research illustrates the need for empirical study of the effects of landscape fragmentation on fundamental demographic processes such as nest predation and brood parasitism in landscapes with diverse histories of natural fragmentation. Explicit comparison of historically fragmented habitats with those that have evolved as contiguous habitat may lead to a more holistic understanding of the impacts of human-caused fragmentation. By combining this work with examination of predator community response to fragmentation, we may gain a more complex, but perhaps more 
complete understanding of the effects of habitat fragmentation.

\section{ACKNOWLEDGMENTS}

For their infallible commitment and enthusiasm through long hours and high water, we would like to thank the nest searchers and censusers of the Bitterroot Riparian Bird Project, especially Wajid Jenkins, Todd Musci, and Jeremy Wheeler. Additional thanks are due to Michael Johnson for radiotelemetry of cowbirds, and to Todd Musci for establishing plots in 1994. For their comments on earlier drafts of this manuscript, we thank Wajid Jenkins, Ray Callaway, Paul Martin, Jennifer Holmes, and Wes Hochachka. For G.I.S. support and facilities, we thank Ken Wall and Michael Sweet. We would also like to thank Keith and Beatrice Evans and the many other private landowners who participated in the project. We thank Therese Donovan, John Rotenberry, and one anonymous reviewer for comments on the manuscript. This research was supported in part by The Bitterroot Ecosystem Management Research Project, Rocky Mountain Research Station, Forestry Sciences Laboratory, Missoula, Montana; with additional funding from the United States Fish and Wildlife Service Non-game Migratory Bird Program; The Montana Cooperative Wildlife Research Unit; the BBIRD (Breeding Biology Research and Monitoring Database) program under the Global Change Research Program of the USBRD; and the Montana Department of Fish, Wildlife and Parks.

\section{Literature Cited}

Ambuel, B., and S. A. Temple. 1983. Area-dependent changes in bird communities and vegetation of southern Wisconsin forests. Ecology 64:1057-1068.

Andrén, H. 1992. Corvid density and nest predation in relation to forest fragmentation: a landscape perspective. Ecology 73:794-804.

1995. Effects of landscape composition on predation rates at habitat edges. Pages 225-255 in L. Hansson, L. L. Fahrig and G. Merriam, editors. Mosaic landscapes and ecological processes. Chapman and Hall, London, UK.

Askins, R. A., J. F. Lynch, and R. Greenberg. 1990. Population declines in migratory birds in eastern North America. Current Ornithology 7:1-57.

Attiwill, P. M. 1994. The disturbance of forest ecosystems: the ecological basis for conservative management. Forest Ecology and Management 63:247-300.

Barber, D. R., and T. E. Martin. 1997. Influence of alternate host densities on brown headed cowbird parasitism rates in black-capped vireos. Condor 99:595-604.

Bock, C. E., V. A. Saab, T. D. Rich, and D. S. Dobkin. 1993. Effects of livestock grazing on neotropical migratory landbirds in Western North America. Pages 296-309 in D. M. Finch and P. W. Stangel, editors. Status and management of neotropical migratory birds. U.S. Forest Service Rocky Mountain Forest and Range Experiment Station General Technical Report RM-229.

Brawn, J. D., and S. K. Robinson. 1996. Source-sink population dynamics may complicate the interpretation of longterm census data. Ecology 77:3-12.

Brittingham, M. C., and S. A. Temple. 1983. Have cowbirds caused forest songbirds to decline? BioScience 33:31-35.

Chasko, G. G., and G. E. Gates. 1982. Avian habitat suitability long a transmission line corridor in an oak-hickory forest region. Wildlife Monographs 82:1-41.

Dobkin, D. S., and B. A. Wilcox. 1986. Analysis of natural forest fragments: riparian birds in the Toyabe Mountains, Nevada. Pages 293-299 in J. Verner, M. L. Morrison, and C. J. Ralph, editors. Wildlife 2000: Modeling habitat relationships of terrestrial vertebrates. University of Wisconsin Press, Madison, Wisconsin, USA.
Donovan, T. M., P. W. Jones, E. M. Annand, and F. R. Thompson III. 1997. Variation in local-scale edge effects: mechanisms and landscape context. Ecology 78:2064-2075.

Donovan, T. M., F. R. Thompson III, J. Faaborg, and J. R. Probst. 1995. Reproductive success of migratory birds in habitat sources and sinks. Conservation Biology 9:13801395.

ESRI. 1989. PC Arc Info version 3.4D. Environmental Systems Research Institute, Inc., Redlands, California, USA.

Faaborg, J., M. Brittingham, T. Donovan, and J. Blake. 1995. Habitat fragmentation in the temperate zone. Pages 357380 in T. E. Martin and D. Finch, editors. Ecology and management of neotropical migratory birds: a synthesis and review of critical issues. Oxford University Press, New York, New York, USA.

Freemark, K., and B. Collins. 1992. Landscape ecology of birds breeding in temperate forest fragments. Pages 443454 in J. M. Hagan and D. W. Johnson, editors. Ecology and conservation of neotropical migrant landbirds. Smithsonian Institution Press, Washington, D.C., USA.

Gates, J. E., and N. R. Griffen. 1991. Neotropical migrant birds ad edge effects at a forest-stream ecotone. Wilson Bulletin 103:204-217.

Gates, J. E., and L. W. Gysel. 1978. Avian nest dispersion and fledgling success in field-forest ecotones. Ecology 59: $871-883$.

Hansen, P. L., R. D. Pfister, K. Boggs, B. J. Cook, J. Joy, and D. K. Hinckley. 1995. Classification and management of Montana's riparian and wetland sites. University of Montana Miscellaneous Publication 54. Montana Forest and Conservation Experiment Station, Missoula, Montana, USA.

Haskell, D. G. 1995. A reevaluation of the effects of forest fragmentation on rates of bird-nest predation. Conservation Biology 9:1316-1318.

Hejl, S. J. 1992. The importance of landscape patterns to bird diversity: a perspective from the northern Rocky Mountains. Northwest Environmental Journal 8:119-137.

- 1994. Human-induced changes in bird populations in coniferous forest in western North America during the past 100 years. Pages 232-246 in J. R. Jehl, Jr., and N. K. Johnson, editors. A century of avifaunal change in western North America. Studies in Avian Biology 15.

Hensler, G. L., and J. D. Nichols. 1981. The Mayfield method of estimating nesting success: a model, estimators and simulation results. Wilson Bulletin 93:42-53.

Hines, J. E., and J. R. Sauer. 1989. CONTRAST Program for the analysis of several survival or recovery rate estimates. Patuxent Wildlife Research Center, U.S. Fish and Wildlife Service, Laurel, Maryland, USA.

Howe, R. W. 1984. Local dynamics of bird assemblages in small forest fragments in Australia and North America. Ecology 65:1585-1601.

Hutto, R. L., S. M. Pletschet, and P. Hendricks. 1986. A fixed radius point count method for nonbreeding and breeding season use. Auk 103:593-602.

Johnson, D. H. 1979. Estimating nest success: the Mayfield method and an alternative. Auk 96:651-661.

Johnson, R. R., L. T. Haight, and J. M. Simpson. 1977. Endangered species vs. endangered habitats: a concept. Pages 86-79 in R. R. Johnson and D. A. Jones, editors. Importance, preservation, and management of riparian habitat: a symposium. Fort Collins, Colorado. U.S. Forest Service General Technical Report RM-43.

Knopf, F. L. 1985. Significance of riparian vegetation to breeding birds across an altitudinal cline. Pages 105-111 in R. R. Johnson, C. D. Ziebell, D. R. Patton, P. F. Ffolliot, and R. H. Hamre, editors. Riparian ecosystems and their management: reconciling conflicting uses. U.S. Forest Service General Technical Report RM-120. 
Knopf, F. L., R. R. Johnson, T. Rich, F. B. Samson, and R. C. Szaro. 1988. Conservation of riparian ecosystems in the United States. Wilson Bulletin 100:272-282.

Martin, T. E. 1987. Artificial nest experiments: affect of nest appearance and type of predators. Condor 89:925-928.

1992. Breeding productivity considerations: what are the appropriate habitat features for management? Pages 455-473 in J. M. Hagan and D. W. Johnston, editors. Ecology and conservation of neotropical migrants. Smithsonian Institution Press, Washington, D.C., USA.

1993a. Nest predation and nest sites: new perspectives on old patterns. BioScience 43:1-18.

1993b. Nest predation among vegetation layers and habitat types: revising the dogmas. American Naturalist 141:897-913.

1995. Avian life history evolution in relation to nest sites, predation, and food. Ecological Monographs 65:101127.

- 1996. Fitness costs of resource overlap among coexisting bird species. Nature 380:338-340.

Martin, T. E., and J. Clobert. 1996. Nest predation and avian life-history evolution in Europe versus North America: a possible role of humans? American Naturalist 147:1028 1046.

Martin, T. E., and G. R. Geupel. 1993. Nest-monitoring plots: methods for locating nests and monitoring success. Journal of Field Ornithology 64:507-519.

Martin, T. E., W. Hochachka, C. J. Conway, and J. W. Jenkins. 1996. BBIRD field protocol. Montana Cooperative Wildlife Research Unit, University of Montana, Missoula, Montana, USA.

Mayfield, H. F. 1961. Nesting success calculated from exposure. Wilson Bulletin 73:255-261.

Mayfield, H. F. 1975. Suggestions for calculating nest success. Wilson Bulletin 87:456-466.

McGarigal, K., and B. J. Marks. 1995. FRAGSTATS: spatial pattern analysis program for quantifying landscape structure. U.S. Forest Service General Technical Report PNW 351.

Møller, A. P. 1989. Nest site selection across field-woodland ecotones: the effect of nest predation. Oikos 56:240-246.

Ohmart, R. D. 1994. The effects of human-induced changes on the avifauna of western riparian habitats. Pages 273 285 in J. R. Jehl, Jr., and N. K. Johnson, editors. A century of avifaunal change in western North America. Studies in Avian Biology 15.

Paton, P. W. C. 1994. The effect of edge on avian nest success: how strong is the evidence? Conservation Biology 8 $17-26$.

Pease, C. M., and J. A. Grzybowski. 1995. Assessing the consequences of brood parasitism and nest predation on seasonal fecundity in passerine birds. Auk 112:343-363.

Ratti, J. T., and K. P. Reese. 1988. Preliminary test of the ecological trap hypothesis. Journal of Wildlife Management 52:484-491.

Rice, W. R. 1989. Analyzing tables of statistical tests. Evolution 43:223-225.

Robinson, S. K. 1992. Population dynamics of breeding Neotropical migrants in a fragmented Illinois landscape. Pages 408-418 in J. M. Hagan and D. W. Johnson, editors. Ecology and conservation of neotropical migrant landbirds. Smithsonian Institution Press, Washington, D.C., USA.

Robinson, S. K., F. R. Thompson, T. M. Donovan, D. R. Whitehead, and J. Faaborg. 1995. Regional forest fragmentation and the nesting success of migratory birds. Science 267: 1987-1990.

Robinson, S. K., and D. S. Wilcove. 1994. Forest fragmentation in the temperate zone and its effects on migratory songbirds. Pages 233-249 in K. Young and M. A. Ramos, editors. The conservation of migratory birds in the neotropics. Bird Conservation International, Washington, D.C., USA.

Roper, J. J. 1992. Nest predation experiments with quail eggs: too much to swallow? Oikos 65:528-530.

Rothstein, S. I., J. Verner, and E. Stevens. 1984. Radiotracking confirms a unique diurnal pattern of spatial occurrence in the parasitic Brown-headed Cowbird. Ecology 65:77-88.

Rothstein, S. I., J. Verner, E. Stevens, and L. V. Ritter. 1987. Behavioral differences among sex and age classes and their relation to the efficacy of a control program. Wilson Bulletin 99:322-327.

SPSS. 1996. Advanced statistics. 7.0 update. SPSS, Incorporated, Chicago, Illinois, USA.

Saab, V. A., and C. R. Groves. 1992. Idaho's migratory landbirds: description, habitats and conservation. Idaho department of Fish and Game Nongame Wildlife Leaflet 10.

Sauer, J. R., and B. K. Williams. 1989. Generalized procedures for testing hypotheses about survival and recovery rates. Journal of Wildlife Management 53:137-142.

Small, M. F., and M. L. Hunter. 1988. Forest fragmentation and avian nest predation in forested landscapes. Oecologia 76:62-64.

Szaro, R. C. 1980. Factors influencing bird populations in southwestern riparian forests. Pages 403-418 in M. Degraph, editor. Management of western forests and grasslands for nongame birds. U.S. Forest Service Intermountain Forest and Range Experimental Station General Technical Report INT-86.

Temple, S. A. 1986. Predicting impacts of habitat fragmentation on forest birds: a comparison of two models. Pages 301-304 in J. Verner, M. L. Morrison, and C. J. Ralph, editors. Wildlife 2000: modeling habitat relationships of terrestrial vertebrates. University of Wisconsin Press, Madison, Wisconsin, USA.

Tewksbury, J. J., T. E. Martin, S. J. Hejl, T. Radmen and J. Wheeler. In press. The occurence and relative abundance of cowbirds in a western valley: landscape, vegetation, and host density effects. Studies in Avian Biology.

Thompson, F. R. III. 1994. Temporal and spatial pattern of breeding in brown-headed cowbirds in the Midwestern United States. Auk 111:979-990.

Trail, P. W., and L. F. Baptista. 1993. The impact of Brownheaded Cowbird parasitism on populations of Nuttall's White-crowned Sparrow. Conservation Biology 7:309315.

Verner, J., and L. V. Ritter. 1983. Current status of the brownheaded cowbird in the Sierra National Forest. Auk 100: 355-368.

Villard, M. A., K. Freemark, and G. Merriam, 1992. Metapopulation theory and neotropical migrant birds in temperate forests: an empirical investigation. Pages 474-482 in J. M. Hagan and D. W. Johnson, editors. Ecology and conservation of neotropical migrant landbirds. Smithsonian Institution Press, Washington, D.C., USA.

Wilcove, D. S. 1985. Nest predation in forest tracts and the decline of migratory songbirds. Ecology 66:1211-1214.

Willebrand, T., and V. Marcström. 1988. On the danger of using artificial nests to study predation. Auk 105:378-379.

Woodworth, B. L. In press a. Brood parasitism, nest predation and season-long reproductive success of a tropical island endemic. Condor.

- In press $b$. The invasion of the Shiny Cowbird in the West Indies: modeling the implications for a single-island endemic vireo. Conservation Biology.

Yahner, R. H. 1988. Changes in wildlife communities near edges. Conservation Biology 2:333-339.

Zar, J. H. 1984. Biostatistical analysis. Second edition. Prentice Hall, Englewood Cliffs, New Jersey, USA. 
APPENDIX

Landscape habitat types designated.

\begin{tabular}{|c|c|}
\hline Habitat type & Description \\
\hline Residential structures & all houses and residences \\
\hline Commercial structures & all business buildings \\
\hline Industrial structures & all industrial areas (lumber yards, saw mills) \\
\hline \multicolumn{2}{|r|}{ 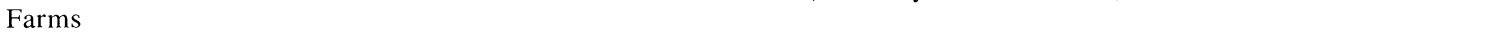 } \\
\hline Animal farm (small) & 1-5 livestock, private farms, 1 corral \\
\hline Animal farm (medium) & 5-15 livestock, large private farms, small training facilities, $1-3$ corrals \\
\hline Animal farm (large) & $\begin{array}{l}>16 \text { livestock, commercial farms, multiple corrals and livestock feeding } \\
\text { areas }\end{array}$ \\
\hline Crop farm & no livestock or livestock feeding areas seen \\
\hline Agricultural land & $\begin{array}{l}\text { most agriculture was used both as cropland and pasture, depending on the } \\
\text { season, and so these uses were not separated }\end{array}$ \\
\hline Orchard & mostly apples \\
\hline Rangeland & all open range, almost exclusively found east of the Bitterroot Valley \\
\hline $\begin{array}{l}\text { Grass rangeland } \\
\text { Shrub rangeland }\end{array}$ & $\begin{array}{l}\text { grass-dominated rangeland } \\
\text { shrub-dominated rangeland }\end{array}$ \\
\hline \multicolumn{2}{|l|}{ Coniferous forest } \\
\hline $\begin{array}{l}\text { Forest } \\
\text { Woodland } \\
\text { Coniferous riparian }\end{array}$ & $\begin{array}{l}\text { closed canopy coniferous forest } \\
\text { open canopy with patches of grassland } \\
\text { mesic coniferous forest along streams }\end{array}$ \\
\hline $\begin{array}{l}\text { Water } \\
\text { Deciduous riparian } \\
\text { Mixed deciduous/coniferous riparian } \\
\text { Recent burn } \\
\text { Other habitats delineated }\end{array}$ & $\begin{array}{l}\text { lakes and reservoirs } \\
\text { all habitats dominated by deciduous species } \\
\text { riparian habitat with near equal portions deciduous and coniferous growth } \\
\text { recently burned areas (mostly } 1994 \text { burns) } \\
\text { meadow, river, sandbar, cattails }\end{array}$ \\
\hline
\end{tabular}

